\title{
PELAKSANAAN PENYIDIKAN TERHADAP ANAK YANG TERLIBAT DALAM TRANSAKSI NARKOTIKA*
}

\author{
Ana Ramadhona \\ Sekolah Tinggi Ilmu Hukum Putri Maharaja Payakumbuh \\ e-mail: ana.ramadhona84@gmail.com
}

\begin{abstract}
One crime that often occurs in Indonesia is drug use. Protection of children in a national society is a benchmark of the nation's civilization, so it must be pursued in accordance with the abilities of the nation. The study was conducted by using an empirical juridical approach. The data used are primary data obtained by interview and secondary data obtained through literature studies. The results of the study are described as follows: As for the implementation of investigations against children involved in narcotics transactions in the jurisdiction of Payakumbuh Police conducted by investigators basically in accordance with the Criminal Procedural Code and Law Number 11 Year 2012 Concerning the Criminal Justice System that applies even though in its implementation it has not maximize due to some limitations. The rights granted to child as suspects are also given in the form of rights avoided from acts of violence, accompanied by legal counsel and social guidance, the right to express opinions, views freely, receive care and welfare, and the right to be treated equally, Obstacles arising in investigations of children involved in Narcotics transactions in the Payakumbuh Police jurisdiction, including the time to detain children is very limited, namely seven days and can be extended eight days so that investigators must be extra fast to be able to complete the case file, should conduct an examination at the BPOM Padang laboratory. It must be also delivered and picked up by investigators and wait for the results of BAPAS research on the child concerned, and the absence of special investigators for children.
\end{abstract}

Keywords: Implementation; Investigation; Children; Transactions; Narcotics.

\begin{abstract}
Abstrak
Salah satu tindak pidana yang sering terjadi di indonesia adalah Narkotika. Perlindungan terhadap anak pada suatu masyarakat bangsa, merupakan tolok ukur peradaban bangsa tersebut karenanya wajib diusahakan sesuai dengan kemampuan nusa dan bangsa. Penelitian dilakukan dengan menggunakan pendekatan yuridis empiris. Data yang digunakan adalah data primer yang diperoleh dengan wawancara serta data sekunder yang diperoleh melalui studi kepustakaan. Hasil penelitian diuraikan sebagai berikut: adapun pelaksanaan penyidikan terhadap anak yang terlibat dalam transaksi narkotika di wilayah hukum Polres Payakumbuh yang dilakukan oleh penyidik pada dasarnya sudah sesuai dengan KUHAP dan Undang-undang Nomor 11 Tahun 2012 Tentang Sistem Peradilan Pidana Anak yang berlaku walaupun dalam pelaksanaannya belum maksimal karena adanya keterbatasan. Hak-hak yang diberikan kepada tersangka anak ini pun diberikan berupa hak dihindari dari tindak kekerasan, didampingi penasehat hukum dan pembimbing kemasyarakatan, hak mengeluarkan pendapat, pandangan secara bebas, mendapat perawatan dan kesejahteraan, dan hak diperlakukan sama, Kendala-kendala yang timbul dalam penyidikan terhadap anak yang terlibat dalam transaksi Narkotika di wilayah hukum Polres Payakumbuh antara lain yaitu waktu untuk melakukan penahanan terhadap anak sangat terbatas yaitu 7 hari dan dapat diperpanjang 8 hari sehingga penyidik harus ekstra cepat untuk bisa menyelesaikan berkas perkaranya, harusnya melakukan pemeriksaan ke laboratorium BPOM Padang yang harus diantar dan dijemput oleh penyidik, harus menunggu hasil penelitian BAPAS terhadap anak yang bersangkutan, dan belum adanya penyidik khusus anak.
\end{abstract}

Kata Kunci : Pelaksanaan; Penyidikan; Anak; Transaksi; Narkotika.

\footnotetext{
* Naskah diterima: 15 Februari 2020, direvisi: 19 Maret 2020, disetujui untuk terbit: 26 Maret 2019

Doi: $10.3376 /$ jch.v5i2.230
} 
Ana Ramadhona: Pelaksanaan Penyidikan Terhadap Anak Yang Terlibat Dalam...

\section{PENDAHULUAN}

Kasus narkoba yang melibatkan anak dibawah umur semakin memprihatinkan. begitu juga untuk wilayah Sumatera Barat menurut data kepolisian ada peningkatan jumlah anak dibawah umur yang terlibat narkoba semakin bertambah. Menurut Diresnarkoba Polda Sumbar pada tahun 2017 ada 6 (enam) anak yang terlibat dalam kasus Narkotika, di tahun 2018 ada 17 (tujuh belas) anak yang terlibat kasus Narkotika di seluruh wilayah Sumatera Barat. Saat ini anak dibawah umur sering dimanfaatkan sebagai pengedar Narkotika.

Permasalahan tentang anak dan perlindungannya tidak akan pernah berhenti sepanjang sejarah kehidupan karena anak adalah generasi penerus pembangunan, yaitu generasi yang dipersiapkan sebagai subyek pelaksana pembangunan yang berkelanjutan dan pemegang kendali masa depan suatu negara, tidak terkecuali Indonesia. Perlindungan anak Indonesia berarti melindungi potensi sumber daya Insan dan membangun manusia Indonesia seutuhnya, menuju masyarakat yang adil dan makmur, materil spiritual berdasarkan Pancasila dan Undang-Undang Dasar 1945 (Nashriana, 2011).

Anak adalah karunia dari Tuhan Yang Maha Esa, dan di dalam diri seorang anak tersebut melekat martabat dan harga dirinya sebagai manusia yang seutuhnya. Seorang anak memiliki potensi untuk maju dan meneruskan cita-cita perjuangan bangsa serta menjadi penjamin keberlangsungan eksistensi Bangsa dan Negara pada masa depan.

Masa anak-anak adalah masa yang sangat rawan untuk melakukan tindakan, karena masa anak-anak suatu masa yang sangat rentan dengan berbagai keinginan dan harapan untuk mencapai sesuatu ataupun melakukan sesuatu. Seorang anak dalam melakukan sesuatu tidak atau kurang menilai akibat akhir tindakan yang diambilnya. (Marlina, 2009)

Faktor internal adalah faktor yang berasal dari dalam diri anak itu sendiri yang mempengaruhi tingkah lakunya, seperti cacat yang bersifat biologis dan psikis dan perkembangan kepribadian dan intelegensi yang terhambat sehingga tidak bisa menghayati norma-norma yang berlaku. Sedangkan faktor eksternal adalah faktor yang berasal dari luar diri anak yang mempengaruhi anak tingkah lakunya. (Marlina, 2009)

Pelanggaran dan kejahatan yang dilakukan oleh anak dapat mengancam mental anak dan masyarakat, Diantaranya keterlibatan anak dalam penyalahgunaan narkotika. Salah satu trend yang mulai berkembang ini adalah keterlibatan anakanak dalam pengedaran Narkotika. Meningkatnya penyalahgunaan narkotika dikalangan anak ini telah mengisi dan menambah pola kriminalitas baru. Oleh karenanya ketika anak menjadi pelaku tindak pidana negara harus memberikan perlindungan kepadanya.

Perlindungan hukum bagi anak dapat diartikan sebagai upaya perlindungan hukum terhadap berbagai kebebasan dan 
hak asasi anak serta berbagai kepentingan yang berhubungan dengan kesejahteraan anak. Jadi masalah perlindungan hukum bagi anak mencakup ruang lingkup yang sangat luas. (Moch Faisal Salam, 2002)

Perlindungan terhadap anak pada suatu masyarakat bangsa, merupakan tolak ukur peradaban bangsa tersebut karenanya wajib diusahakan sesuai dengan kemampuan nusa dan bangsa. Upaya-upaya perlindungan anak harus di mulai sedini mungkin, agar kelak dapat berpartisipasi secara optimal bagi pembangunan bangsa dan negara. Maka diperlukan pembinaan secara terusmenerus terhadap anak demi kelangsungan hidup, pertumbuhan, dan perkembangan fisik, mental serta perlindungan dari segala kemungkinan yang akan membahayakan mereka dan bangsa di masa depan.

Secara hukum Negara Indonesia telah memberikan perlindungan kepada anak melalui berbagai peraturan perundangundangan diantaranya Undang-Undang Nomor 11 Tahun 2012 tentang Sistem Peradilan Pidana Anak dan UndangUndang Nomor 35 Tahun 2014 tentang Perlindungan Anak. Akan tetapi dalam pelaksanaannya sistem peradilan pidana anak di Indonesia masih sering dijumpai penanganan terhadap anak pelaku perbuatan pidana tidak disertai dengan perlindungan hukum, pembinaan yang baik dan jaminan pelaksanaan akan hakhak anak. Persoalan yang ada di antaranya dilakukan penahanan terhadap anak, proses peradilan yang panjang mulai dari penyidikan, penuntutan, pengadilan yang akhirnya menempatkan terpidana anak berada dalam lembaga pemasyarakatan yang meninggalkan trauma dan implikasi negatif terhadap anak. (Rukmana, A. Indra, 2014)

Melihat kenyataan inilah fungsi dan peran kepolisian dalam kedudukannya sebagai aparat yang berwenang melakukan penyelidikan dan penyidikan dituntut untuk menjalankan tugas dan kewajibannya seperti yang telah ditentukan dalam Undang-Undang Nomor 2 Tahun 2002 tentang Kepolisian Negara Republik Indonesia.

Dalam rangka melaksanakan tugasnya sebagai gerbang utama proses peradilan pidana, penyidik polisi menanggung beban yang tidak ringan. Penyidik polisi harus benar-benar menjadi penyidik yang baik, dan juga penilaian yang baik. Penyidik polisi harus melakukan penyaringan-penyaringan terhadap arus perkara yang masuk. Pada dasarnya, tidak semua perkara pidana yang masuk dan diterima oleh penyidik polisi diteruskan ke tahapan peradilan selanjutnya. Penyidik polisi diberi kewenangan kebijakan diskresi untuk melanjutkan atau tidak perkara pidana ke tahap selanjutnya. Peran penyidik polisi dalam penegakan hukum pidana terhadap anak telah diatur dalam Undang-Undang Nomor 11 Tahun 2012 tentang Sistem Peradilan Pidana Anak. (H Dwiatmodjo, 2013)

Penyidik sangat berperan dalam proses penyidikan perkara pidana anak yaitu dengan melakukan tindakan penyelidikan dan penyidikan, hal ini 
Ana Ramadhona: Pelaksanaan Penyidikan Terhadap Anak Yang Terlibat Dalam...

sangat penting dilakukan oleh kepolisian karena bertujuan untuk melindungi hak seorang yang diduga sebagai pelaku tindak pidana. Maka harus ada bukti permulaan yang cukup untuk melakukan penangkapan. Penyidikan sebagai rangkaian dari proses penyelidikan, bermaksud untuk menemukan titik terang siapa pelaku atau tersangkanya. "Penyidikan adalah serangkaian tindakan penyidik dalam hal dan menurut cara yang diatur dalam Kitab Undang-Undang Hukum Acara Pidana (KUHAP) untuk mencari serta mengumpulkan bukti yang dengan bukti itu membuat terang tindak pidana yang terjadi guna menemukan tersangkanya".

Secara nasional Komisi Perlindungan Anak Indonesia (KPAI) menemukan adanya peningkatan keterlibatan anak dalam peredaran gelap Narkotika. Anak semakin sering ditemukan menjadi kurir hingga korban penyalahgunaan narkoba. Total ada 7 (tujuh) juta anak yang berusia maksimal 18 (delapan belas) tahun tercatat 5.9 juta terpapar sebagai pecandu narkoba, 27 persen diantaranya anak-anak yakni 1,6 juta anak sebagai pengedar. Khusus untuk Polres Payakumbuh telah menangani beberapa kasus yang berkaitan dengan anak sebagai pelaku tindak pidana yang berkaitan dengan kasus Narkotika. Sepanjang tahun 2018 sampai dengan tahun 2019 tercatat ada 2 (dua) kasus yang melibatkan anak sebagai pelaku tindak pidana yaitu antara lain pertama kasus atas nama $\mathrm{AB}$, jenis kelamin lakilaki yang pada saat tertangkap berumur 17 tahun, diperiksa sebagai Anak
Berhadapan dengan Hukum yang mana tanpa hak atau melawan hukum menjual, membeli, menjadi perantara dalam jual beli, menerima atau menyerahkan Narkotika Gol I bukan tanaman jenis sabu. AB tertangkap pada hari Minggu tanggal 18 Februari 2018. Kedua yaitu kasus atas nama Ilh, jenis kelamin lakilaki, yang pada saat tertangkap berumur 16 (enam belas) tahun, diperiksa sebagai Anak Berhadapan dengan Hukum yang mana tanpa hak atau melawan hukum menawarkan untuk dijual, menjual, membeli, menjadi perantara dalam jual beli, menukar atau menyerahkan Narkotika Gol I dalam bentuk tanaman jenis Ganja. Ilh tertangkap pada hari Senin tanggal 20 Agustus 2018 di Kecamatan Luak Kabupaten Lima Puluh Kota.

Mengingat semakin banyaknya anakanak yang terlibat dalam penyalahgunaan narkoba dengan ciri dan sifat yang khas pada anak dan demi perlindungan terhadap anak, maka proses peradilan perkara yang melibatkan anak harus dilakukan oleh pejabat khusus yang memahami masalah anak.

\section{METODE PENELITIAN}

Pendekatan yang di gunakan dalam penelitian ini adalah pendekatan Yuridis Empiris, pendekatan Yuridis (Hukum dilihat sebagai Norma atau das solen) karena dalam membahas permasalahan penelitian ini menggunakan bahan-bahan hukum tertulis, kemudian bahan hukum primer dan bahan hukum sekunder, pendekatan empiris (Hukum sebagai kenyataan social, cultural atau das sein), 
karena dalam penelitian ini menggunakan data premier yang diperoleh dari lapangan.

Jadi, Pendekatan Yuridis empiris dalam penelitian ini maksudnya adalah bahwa dalam menganalisis permasalahan dilakukan dengan cara memadukan bahan-bahan hukum (yang merupakan data sekunder) dengan data premier yang diperoleh dari lapangan yaitu Pelaksanaan Penyidikan Terhadap Anak Yang Terlibat Transaksi Narkotika Di Wilayah Hukum Polres Payakumbuh.

\section{HASIL DAN PEMBAHASAN}

\section{Pelaksanaan Penyidikan Terhadap Anak Yang Terlibat Dalam Transaksi Narkotika Di Wilayah Hukum Polres Payakumbuh}

Kepolisian Resor Payakumbuh sebagai salah satu bagian dari Kepolisian Republik Indonesia, dalam perannya untuk menegakkan hukum pidana tidak pernah berhenti bersinggungan langsung dengan kehidupan masyarakat. Salah satu bagian yang tidak pernah lepas dari kehidupan masyarakat tersebut dari Kepolisian Resor Payakumbuh adalah Unit Satresnarkoba (Satuan Reserse Narkoba) Kepolisian Resor Payakumbuh.

Pelaksanaan penyidikan terhadap orang yang terlibat dalam transaksi Narkotika, tahapan yang dilakukan antara lain pertama dimulai dari sumber tindakan (laporan aduan, tertangkap tangan atau diketahui langsung oleh petugas). Kedua dilakukan penyelidikan dengan cara penganan TKP, interview, observasi dan surveilance. Ketiga dilakukan penyidikan dengan cara upaya paksa (pemanggilan, penangkapan, penahanan, penggeledahan, dan penyitaan) dan kemudian ada pemeriksaan terhadap saksi, saksi ahli dan terhadap tersangka. Keempat akhir dari proses penyidikan tersebut yaitu penyusunan berkas perkara, pemberkasan dan penyerahan berkas perkara tersebut ke Kejaksaan Negeri yaitu kepada Jaksa Penuntut Umum.

Tapi dalam proses penyidikan terhadap tindak pidana Narkotika yang dilakukan oleh anak, proses yang berbeda adalah hanya pada perlakuan terhadap tersangka dan pada penahanan tersangka anak saja, yaitu dipisahkan dengan tempat penahanan untuk orang dewasa. Ketentuan ini sesuai dengan Undangundang Nomor 11 Tahun 2012 tentang Sistem Peradilan Pidana Anak (UUSPPA). Kesesuaian pihak yang berwajib dalam melakukan penyelidikan terhadap anak tersebut pada dasarnya sudah sesuai dengan KUHAP dan Undang-undang Sistem Peradilan Pidana Anak yang berlaku. Selain itu penyidik pun memberikan perlindungan hukum berupa pemberian hak kepada tersangka anak yang ditentukan dalam Undangundang Sistem Peradilan Pidana Anak. Hak-hak yang diberikan kepada tersangka anak ini yaitu hak dihindari dari tindak kekerasan, didampingi penasehat hukum dan pembimbing kemasyarakatan, hak dianggap tidak bersalah selama dalam proses peradilan, hak tidak dirampas kemerdekaannya, hak mengeluarkan pendapat, pandangan secara bebas, 
Ana Ramadhona: Pelaksanaan Penyidikan Terhadap Anak Yang Terlibat Dalam...

mendapat perawatan dan kesejahteraan, dan hak diperlakukan sama.

Berdasarkan hasil wawancara dengan Ajun Komisaris Polisi Satu Elvi Piliang, S.H, jabatan sebagai Kasat Resnarkoba Polres Payakumbuh, selaku penyidik telah melakukan pemeriksaan terhadap anak yang bernama Ananda Barokah, berumur 17 tahun, pekerjaan pelajar di SMA 01 Akabiluru, jenis kelamin laki-laki, agama Islam, yang bertempat tinggal di Jorong Sungai Cubadak kenagarian Koto Tangah Batu Ampa Kecamatan Akabiluru Kabupaten Lima Puluh Kota. Ananda Baroqah diperiksa sebagai Anak yang berhadapan dengan hukum dalam perkara tindak pidana yang tanpa hak atau melawan hukum menjual, membeli, menjadi perantara dalam jual beli, menerima atau menyerahkan Narkotika Gol I bukan tanaman jenis sabu. Sebelum pemeriksaan dilakukan penyidik terlebih dahulu memberitahukan hak-haknya sebagai anak yang berhadapan dengan hukum, terutama hak didampingi oleh Pengacara atau Penasehat Hukum selama proses pemeriksaan oleh pihak kepolisian.

Pada saat pemeriksaan Ananda Baroqah didampingi oleh Penasehat Hukum Setia Budi S.H., M.H dan orangtua laki-lakinya yang bernama Yusra, pemeriksaan dilakukan secara tanya jawab, pada saat diperiksa Ananda dalam keadaan sehat jasmani dan Rohani, ananda baru pertama kali melakukan Tindak Pidana khususnya Narkotika, ditangkap bersama temannya bernama Fegri, saat ditangkap polisi menyita 1 paket sedang yang diduga Narkotika Gol I yang terbungkus plastik bening dibalut dengan tisu dan disimpan di kotak rokok Sampoerna Mild putih yang saat itu digenggam dengan tangan kanan, pada saat penangkapan juga disaksikan oleh Wali Nagari dan Wali Jorong, Ananda mau menjadi perantara karena diimingi keuntungan upah Rp. 50.000 setiap selesai mengantar paket. Pada saat memberikan keterangan tersebut Ananda tidak ada merasa terpaksa dan dipengaruhi oleh siapa pun dan menyatakan bahwa keterangan yang diberikan adalah sudah dengan sebenarbenarnya.

Pemidanaan terhadap anak berdasarkan Undang-Undang Nomor 11 Tahun 2012 tentang Sistem Peradilan Pidana Anak merupakan suatu landasan penjatuhan sanksi terhadap anak yang melakukan tindak pidana. (A Sudanto, 2017)

Terhadap anak yang menjadi perantara jual beli narkotika, UndangUndang Nomor. 35 Tahun 2009 tentang Narkotika tidak secara khusus mengatur mengenai ketentuan sanksi pidana bagi anak, namun pada dasarnya jika seorang anak yang melakukan tindak pidana Narkotika dimana seorang anak yang menjadi perantara jual beli untuk menjalankan suatu proses peredaran gelap Narkotika tetap dijerat dengan pasal-pasal sebagaimana yang ditentukan dalam ketentuan pidana yang diatur dalam Undang-Undang Narkotika, tetapi tidak mengesampingkan ketentuan khusus yang diatur dalam Undang-Undang Nomor. 11 Tahun 2012 tentang Sistem Peradilan 
Pidana Anak. (Fransiska N Eleanora, 2011)

Dari hasil penelitian yang penulis lakukan terhadap penyidikan yang dilakukan oleh Unit Satresnarkoba di wilayah hukum Polres Payakumbuh dapat dilihat bahwa selama proses penyidikan, peran penyidik anak berupa melakukan penangkapan dan penahanan anak, apabila penahanan anak sudah berakhir maka penyidik akan menyerahkan anak beserta barang bukti kepada kejaksaan untuk dilakukan pemeriksaan, terhadap anak yang menjalani Berita Acara Pemeriksaan (BAP) wajib didampingi oleh pekerja sosial, penasehat hukum dan Badan Pemasyarakatan (BAPAS).

Penyidikan terhadap anak yang terlibat dalam transaksi Narkotika di Wilayah Hukum Polres Payakumbuh dilaksanakan sesuai dengan prosedur yang berlaku, tetapi pelaksanaan tersebut masih belum bisa maksimal dikarenakan waktu penahanan terhadap tersangka anak terbatas. Sedangkan waktu untuk melakukan penyidikan perkara tersebut bisa melebihi batas penahanan terhadap tersangka.

Semakin meningkatnya angka penyalahgunaan Narkotika oleh anak membawa konsekuensi logis seorang anak akan sering berhadapan dengan aparat penegak hukum, dalam hal ini kepolisian sebagai ujung tombak proses penegakan hukum. Oleh karena itu dalam menjalankan tugasnya terutama di dalam menangani kasus tindak pidana Narkotika yang dilakukan oleh anak, polisi harus bertindak tepat agar tindak pidana yang dilakukan anak tidak terjadi secara berulang dan tidak mempengaruhi proses perkembangan kedewasaan anak, antara lain dengan melakukan penyidikan tanpa kekerasan dan dilakukan dengan tetap mempertimbangkan aspek psikologi anak.

Penyidik terhadap perkara anak nakal dilakukan oleh polri. Sesuai dengan yang dinyatakan dalam Pasal 41 ayat (1) Undang-Undang tentang Sistem Peradilan Pidana Anak yang menyatakan bahwa penyidik terhadap anak nakal, dilakukan oleh penyidik yang ditetapkan oleh penyidik yang ditetapkan berdasarkan Surat Keputusan Kepala Kepolisian Republik Indonesia atau pejabat lain yang ditunjuk oleh Kepala Kepolisian Republik Indonesia.

Hal ini berarti juga bahwa tidak semua penyidik dapat menjadi penyidik dalam perkara anak, karena hanya yang mendapatkan kewenangan dari Kapolri untuk menjadi penyidik anak. Eksepsionisnya terhadap hal-hal tertentu karena penyidik anak tidak ada maka penyidik dalam perkara biasa dapat menjadi penyidik bagi perkara anak, dasar hukumnya Pasal 41 ayat (3) UndangUndang tentang Sistem Peradilan Pidana Anak. Syarat untuk menjadi penyidik anak yaitu penyidik yang telah berpengalaman sebagai penyidik tindak pidana yang dilakukan oleh orang dewasa serta harus mempunyai minat, perhatian, dedikasi dan memahami masalah yang berkenaan dengan anak.

Penyidikan yang dilakukan oleh penyidik anak tersebut harus dikemas dalam suasana kekeluargaan. Yang 
Ana Ramadhona: Pelaksanaan Penyidikan Terhadap Anak Yang Terlibat Dalam...

dimaksud dengan "dalam suasana kekeluargaan" antara lain pada waktu memeriksa tersangka, penyidik tidak memakai pakaian dinas dan melakukan pendekatan secara efektif, afektif, dan simpatik. Efektif dapat diartikan, bahwa pemeriksaannya tidak memakan waktu lama dengan menggunakan bahasa yang mudah dimengerti dan dapat mengajak terdakwa untuk memberikan keterangan yang sejelas-jelasnya. Sedang simpatik dapat diartikan pada waktu pemeriksaan, penyidik bersikap sopan dan ramah serta tidak menakut-nakuti terhadap tersangka. (Ika R Utami, 2014)

Suasana kekeluargaan itu juga berarti tidak ada pemaksaan, intimidasi atau sejenisnya selama dalam penyidikan. Sekali lagi ini menunjukkan perlindungan hukum terhadap anak meskipun telah menjabat sebagai pelaku tindak pidana.

Di sisi lain penyidik anak tersebut wajib untuk meminta pertimbangan atau saran dari pembimbing kemasyarakatan atau jika perlu kepada ahli pendidikan, ahli kesehatan jiwa, ahli agama, atau petugas kemasyrakatan lainnya, dasar hukumnya tercantum dalam Pasal 42 Undang-Undang tentang Sistem Peradilan Pidana Anak. Proses penyidikan ini juga harus dirahasiakan agar tidak dengan mudah dapat diketahui umum yang dapat menyebabkan depresi, malu atau minder dan lain sebagainya yang nantinya berakibat secara psikis terhadap tumbuh kembangnya anak di masyarakat.

Penangkapan adalah suatu tindakan penyidik berupa pengekangan sementara waktu kebebasan tersangka atau terdakwa apabila terdapat cukup bukti guna kepentingan penyidikan atau penuntutan dan atau peradilan dalam hal dan menurut cara yang diatur oleh undang-undang. Begitulah setidaknya pengertian yang di cantumkan dalam Pasal 1 angka 20 KUHAP yang berlaku terhadap anak nakal pula, dengan kata lain penangkapan anak nakal mengikuti tata cara dalam KUHAP.

Penangkapan dilakukan tidak boleh dengan sewenang-wenang, oleh karena itu harus penangkapan hanya boleh dilakukan berdasarkan surat perintah dari penyidik kecuali karena tertangkap tangan yakni dengan harus segera menyerahkan tertangkap itu beserta dengan barang buktinya kepada penyidik. Penangkapan itu dilakukan paling lama satu hari (1x24 jam) oleh polri.

Dalam Pasal 32 Undang-undang Sistem Peradilan Pidana anak, Penahanan terhadap anak tidak boleh dilakukan dalam hal memperoleh jaminan dari orang tua atau lembaga bahwa anak tidak melarikan diri, menghilangkan barang bukti atau merusak barang bukti atau tidak akan mengulangi tindak pidana.

Penahanan dapat dilakukan dengan syarat antara lain:

a. Umur anak 14 (empat belas) tahun;

b. Diduga melakukan tindak pidana dengan ancaman pidana penjara selama 7 (tujuh) tahun atau lebih. (Hariyanto, Bayu P, 2018).

Penahanan terhadap anak tentunya berbeda pula dengan terdakwa (dewasa) dan terhadap penahanan terhadap anak 
yang berkonflik hukum tersebut yakni penahanan oleh Penyidik paling lama 7 (tujuh) hari dan dapat diperpanjang oleh Penuntut Umum selama 8 (delapan) hari, sedangkan terhadap terdakwa dewasa 20 (dua puluh) hari dengan perpanjangan 40 (empat puluh) hari.

Penyidik di Polres Payakumbuh khususnya bagian Satuan Reserse Narkoba (Satresnarkoba) Polres Payakumbuh sudah berusaha semaksimal mungkin agar pelaksanaan penyidikan terhadap anak yang terlibat dalam transaksi Narkoba ini sesuai dengan aturan yang ditetapkan dalam KUHAP dan Undang-Undang tentang Sistem Peradilan Pidana Anak, walaupun masih ada kendala-kendala dalam pelaksanaannya seperti waktu yang terbatas, lamanya proses di laboratorium, menunggu hasil penelitian dari pihak BAPAS, dan belum tersedianya penyidik khusus anak.

\section{Kendala Dalam Penyidikan Terhadap Anak Yang Terlibat Dalam Transaksi Narkotika Di Wilayah Hukum Polres Payakumbuh}

Pelaksanaan proses penyidikan yang dilakukan oleh penyidik apalagi kasus tersebut berkaitan dengan tindak pidana yang dilakukan oleh anak tidak selamanya dapat berjalan dengan baik, karena terkadang penyidik dalam melakukan proses penyidikan terhadap anak sebagai pelaku sering kali mendapatkan kendalakendala dalam proses pelaksanaannya. Begitu juga halnya yang terjadi dalam pelaksanaan penyidikan yang dilakukan penyidik terhadap kasus narkotika yang melibatkan anak juga mendapatkan kendala-kendala dalam pelaksanaan penyidikannya.

Adapun kendala-kendala yang ditemui penyidik dalam menjalankan proses penyidikan terhadap anak yang terlibat dalam transaksi narkotika di wilayah hukum Polres Payakumbuh berdasarkan hasil wawancara dengan bapak Brigadir Refki Saputra S.IP antara lain :

1. Pelaksanaan penahanan terhadap anak menurut Undang-undang tentang Sistem Peradilan Anak pasal 33 ayat 1 dan 2 menyatakan bahwa penahanan hanya dapat dilakukan selama 7 (tujuh) hari dan perpanjangan penahanan selama 8 (delapan) hari sehingga jika dijumlahkan hanya 15 hari kerja. Dengan waktu yang sangat terbatas tersebut penyidik diharuskan bekerja ekstra cepat untuk menyelesaikan berkas perkaranya supaya tidak melebihi waktu yang telah ditentukan.

2. Pemeriksaan laboratorium di BPOM Padang.

Untuk pemeriksaan ke laboratorium penyidik yang harus mengantar langsung ke BPOM Padang dan kemudian penyidik lagi yang harus mengambil hasil laboratorium tersebut ke Padang. Untuk cek Laboratorium ini diperlukan waktu lebih kurang 10 (sepuluh) hari kerja.

3. Lamanya penelitian dari Badan Pemasyarakatan (BAPAS) dalam hal ini BAPAS Biaro. 
Ana Ramadhona: Pelaksanaan Penyidikan Terhadap Anak Yang Terlibat Dalam...

Dalam proses penyidikan terhadap tindak pidana Narkotika di Polres Payakumbuh yang dilakukan oleh anak, pihak penyidik dari Polres Payakumbuh selain menggunakan KUHAP sebagai acuan dalam penyidikan juga menggunakan Undang-Undang Nomor. 11 Tahun 2012 tentang Sistem Peradilan Pidana Anak. Sehingga dalam melakukan penyidikan para penyidik meminta kepada Badan Pemasyarakatan untuk melakukan penelitian terhadap anak tersebut sebagai pelaku.

Dalam melakukan penyidikan terhadap tindak pidana Narkotika yang dilakukan oleh anak akan memakan waktu yang cukup lama dikarenakan menunggu hasil penelitian dari Badan Pemasyarakatan (BAPAS), sementara waktu penahanan terhadap anak sebagai pelaku sangat terbatas. Berdasarkan hasil wawancara dengan Randi Hermawan S.H selaku penyidik di Polres Payakumbuh, walaupun jangka waktu penahanan terhadap anak sangat terbatas, penyidikan tidak mengalami keterlambatan. Beliau juga mengatakan bahwa lamanya penyerahan hasil Penelitian dari Badan Pemasyarakatan dikarenakan jumlah anak sebagai pelaku sangat banyak sehingga membuat petugas Badan Pemasyarakatan harus memerlukan waktu yang cukup lama untuk menyelesaikan penelitian tersebut.

4. Belum tersedianya penyidik khusus untuk anak karena keterbatasan Sumber Daya Manusia (SDM) di Polres Payakumbuh
Dalam pasal 26 ayat 3 Undangundang Nomor 11 Tahun 2012 dinyatakan bahwa syarat untuk dapat ditetapkan sebagai Penyidik sebagaimana dimaksud pada ayat (1) meliputi:

a. Telah berpengalaman sebagai Penyidik

b. Mempunyai minat, perhatian, dedikasi dan memahami masalah anak dan;

c. Telah mengikuti pelatihan teknis tentang Peradilan Anak.

Penyidik Anak yang memiliki peran untuk mengimplementasikan tugas dan wewenangnya sebagai penyidik khusus dalam melakukan penyidikan dan perlindungan terhadap anak yang berhadapan dengan hukum. Anak yang berhadapan dengan hukum harus mendapatkan perlakuan khusus yang bertujuan untuk melindungi hak-hak anak yang berhadapan dengan hukum dari kesewenang-wenangan penegak hukum. Komitemen, perhatian, kemampuan, dedikasi, serta minat harus dimiliki dan dilaksanakan oleh Penyidik Anak dalam melaksanakan segala bentuk tindakan perlindungan terhadap anak sebagai pelaku tindak pidana perdagangan orang pada tahap penyidikan agar anak terlindungi dari kekerasan dan diskriminasi. (Zahra, A, 2017).

Penangkapan terhadap anak dilakukan tidak boleh dengan sewenangwenang, oleh karena itu penangkapan hanya boleh dilakukan berdasarkan surat perintah dari penyidik kecuali karena tertangkap tangan yakni dengan harus segera menyerahkan tertangkap itu 
beserta dengan barang buktinya kepada penyidik. Penangkapan itu dilakukan paling lama satu hari $(1 \times 24$ jam $)$ oleh polri. Anak wajib ditempatkan dalam ruang pelayanan khusus anak, penangkapan anak wajib dilakukan secara manusiawi dengan memperhatikan kebutuhan sesuai dengan umurnya. Pejabat yang melakukan penangkapan wajib memberitahukan kepada Anak dan orang tua/Wali mengenai hak memperoleh bantuan hukum.

Berdasarkan ketentuan UndangUndang Nomor 11 Tahun 2012 tentang Sistem Peradilan Pidana Anak diketahui penahanan anak pada tahap penyidikan hanya selama 7 (tujuh) hari. Jangka waktu penahanan dapat diperpanjang lagi untuk paling lama 8 (delapan) hari. Singkatnya masa penahanan ini membuat penyidik harus bekerja secara ekstra cepat untuk menyelesaikan berkas perkaranya.

Untuk pemeriksaan ke laboratorium penyidik sendiri yang harus mengantar langsung ke BPOM padang dan kemudian penyidik lagi yang harus mengambil hasil laboratorium tersebut ke Padang. Untuk cek Laboratorium ini waktu yang diperlukan lebih kurang 10 (sepuluh) hari kerja.

Dalam melakukan penyidikan para penyidik meminta kepada Badan Pemasyarakatan untuk melakukan penelitian terhadap anak tersebut sebagai pelaku. Sesuai dengan yang diamanatkan dalam Undang-Undang, dalam melakukan penyidikan terhadap anak nakal, penyidik wajib meminta pertimbangan atau saran dari Pembimbing Kemasyarakatan, dan apabila perlu juga dapat meminta pertimbangan atau saran dari ahli pendidikan, ahli kesehatan jiwa, ahli agama, atau petugas kemasyarakatan lainnya. Balai Pemasyarakatan (BAPAS) merupakan pranata yang sangat penting di dalam peradilan pidana anak namun keberadaannya kurang mendapat perhatian seolah-olah peranan yang banyak tampil dalam penanganan anak yang melakukan kejahatan itu hanyalah penyidik, jaksa, hakim dan petugas pemasyarakatan. (Helviza. 2016).

Keterlibatan BAPAS di mulai sejak anak dalam tahap penyidikan. Badan Pemasyarakatan (BAPAS) dalam melakukan penelitian terhadap anak sebagai pelaku tindak pidana bertugas membantu memperlancar tugas penyidik, penuntut umum, dan hakim dalam perkara anak nakal, baik di dalam maupun di luar sidang anak. Adapun petugas kemasyarakatan terdiri dari:

a. Pembimbing Kemasyarakatan dari Departemen Kehakiman,

b. Pekerja Sosial dari Departemen Sosial

c. Pekerja Sosial sukarela dari Organisasi Sosial Kemasyarakatan.

Dalam melakukan penyidikan terhadap tindak pidana Narkotika yang dilakukan oleh anak akan memakan waktu yang cukup lama dikarenakan menunggu hasil penelitian dari Badan Pemasyarakatan (BAPAS), sementara waktu penahanan terhadap anak sebagai pelaku sangat terbatas. Berdasarkan hasil wawancara dengan Randi Hermawan S.H selaku penyidik di Polres Payakumbuh, 
Ana Ramadhona: Pelaksanaan Penyidikan Terhadap Anak Yang Terlibat Dalam...

walaupun jangka waktu penahanan terhadap anak sangat terbatas, penyidikan tidak mengalami keterlambatan. Beliau juga mengatakan bahwa lamanya penyerahan hasil Penelitian dari Badan Pemasyarakatan dikarenakan jumlah anak sebagai pelaku sangat banyak sehingga membuat petugas Badan Pemasyarakatan (BAPAS) harus memerlukan waktu yang cukup lama untuk menyelesaikan penelitian tersebut.

Penyidik terhadap perkara anak nakal dilakukan oleh Polri. Sesuai dengan yang dinyatakan dalam Pasal 41 ayat (1) Undang-undang tentang Sistem Peradilan Pidana Anak menyatakan bahwa penyidik terhadap anak nakal, dilakukan oleh penyidik yang ditetapkan berdasarkan Surat Keputusan Kepala Kepolisian Republik Indonesia atau pejabat yang lain yang ditunjuk oleh Kepala Kepolisian Republik Indonesia. Hal ini berarti bahwa tidak semua penyidik dapat menjadi penyidik dalam perkara anak, karena hanya yang mendapat kewenangan dari KAPOLRI untuk menjadi penyidik anak. konsepsionisnya terhadap hal-hal tertentu karena penyidik anak tidak ada maka penyidik dalam perkara biasa dapat menjadi penyidik bagi perkara anak, hal ini sesuai dengan pasal 41 ayat (3) Undang-undang Sistem Peradilan Pidana Anak.

\section{Upaya Yang Dilakukan Dalam Mengatasi Kendala-Kendala Dalam Penyidikan Terhadap Anak Yang Terlibat Dalam Transaksi Narkotika Di Wilayah Hukum Polres Payakumbuh}

Adanya perbedaan pelaksanaan penyidikan dan penyidik yang melakukan penyidikan terhadap anak yang berhadapan dengan hukum, memaksa penyidik harus ekstra hati-hati dalam melakukan penyidikan.

Berdasarkan kendala-kendala yang dihadapi diatas maka ada beberapa upayaupaya yang dilakukan oleh Polres Payakumbuh agar pelaksanaan penyidikan terhadap anak yang terlibat dalam tindak pidana narkotika dapat berjalan sesuai ketentuan dalam KUHAP dan Undang-undang tentang Sistem Peradilan Pidana Anak yaitu :

a. Meningkatkan kemampuan penyidik dalam melakukan penyidikan sehingga mampu menyelesaikan perkara selama jangka waktu anak ditahan sesuai dengan aturan yaitu 7 (hari) kerja dan dapat perpanjang penahanan 8 (delapan) hari kerja.

b. Meningkatkan kerja sama dengan BPOM Padang agar hasil laboratorium dapat dikeluarkan sesegera mungkin tanpa harus menunggu sampai 10 (sepuluh) hari kerja.

c. Meningkatkan hubungan kerja sama dengan BAPAS agar penelitian dan hasil penelitian terhadap anak dapat diselesaikan dengan segera. Sehingga Hasil penelitian tersebut dapat 
diselesaikan dengan segera sebelum pihak penyidik menyerahkan anak dan barang bukti kepada Jaksa Penuntut Umum (JPU).

Mengupayakan agar penyidik yang ada di Polres Payakumbuh juga bisa diangkat menjadi penyidik anak berdasarkan Surat Keputusan Kepala Kepolisian Republik Indonesia atau pejabat yang lain yang ditunjuk oleh Kepala Kepolisian Republik Indonesia. Karena untuk menjadi penyidik anak harus berasal dari penyidik yang sudah berpengalaman.

Tidak sedikit anak Indonesia yang terjerumus ke lubang hitam penyalahgunaan narkoba. Dalam hal ini peran orang tua sangat diperlukan untuk melindungi anak-anak dari jeratan obatobatan terlarang. Kebijakan pembentukan perangkat hukum untuk mengatasi masalah anak yang berkonflik dengan hukum melalui proses peradilan pidana anak tidak berpengaruh signifikan bagi menurunnya kasus anak yang berkonflik dengan hukum. Belum ada konsep atau resep hukum yang berhasil mengatasi masalah anak secara tuntas.

Dalam banyak kasus anak yang terlibat narkoba penyebabnya adalah pengaruh orang dewasa. Mereka sengaja memanfaatkan anak sebagai pengedar, alat dan media transaksi narkoba atau bahkan media promosi narkoba. Keluarga dan sekolah harus menjadi proteksi pertama dan utama dari kejahatan narkoba untuk menjadikan generasi Indonesia bermartabat.
Adanya perbedaan pelaksanaan penyidikan dan penyidik yang melakukan penyidikan terhadap anak yang berhadapan dengan hukum, memaksa penyidik harus ekstra hati-hati dalam melakukan penyidikan.

Minimnya waktu yang dimiliki penyidik kepolisian dalam menyidik perkara yang melibatkan anak, membuat kualitas penyidikan serba terburu-buru. Padahal penyidik itu tidak hanya kepolisian saja tetapi juga dari pihak kejaksaan. Penyidik hanya diberi waktu selama 7 (tujuh) hari untuk anak berumur 12 (dua belas) sampai 14 (empat belas) tahun. Waktu yang terbatas itu harus bisa dimanfaatkan semaksimal mungkin. Pihak penyidik berharap agar aturan-aturan yang kurang menguntungkan dalam menyidik dapat menjadi pertimbangan pihak pembuat Undang-undang supaya hasil penyidikan lebih terjamin dan jauh dari kesan terburu-buru.

Polres Payakumbuh sudah berupaya semaksimal mungkin dan disesuaikan dengan psikologis anak yang masih rentan. Anak sebagai subjek hukum yang masih berkembang harus diberi perhatian khusus terutama morilnya.

Polres payakumbuh berupaya untuk memberikan pelayanan terbaik dalam menyidik anak. Menyediakan ruangan yang jauh dari nuansa polisi atau nuansa orang dewasa. Dalam melakukan penyidikan terhadap kasus yang berkaitan dengan Narkoba, penyidik juga bekerja sama dengan BPOM padang dalam melakukan penyidikan. Selama ini untuk penanganan Narkoba penyidik 
Ana Ramadhona: Pelaksanaan Penyidikan Terhadap Anak Yang Terlibat Dalam...

mengujikan sampel di laboratorium BPOM. BPOM berwenang melakukan pengujian Narkotika dan Psikotropika dalam bentuk bahan baku dan obat jadi.

Selain itu sesuai dengan yang diamanatkan dalam Undang-Undang, dalam melakukan penyidikan terhadap anak nakal, penyidik wajib meminta pertimbangan atau saran dari Pembimbing Kemasyarakatan, dan apabila perlu juga dapat meminta pertimbangan atau saran dari ahli pendidikan, ahli kesehatan jiwa, ahli agama, atau petugas kemasyarakatan lainnya. Badan Pemasyarakatan (BAPAS) dalam melakukan penelitian terhadap anak sebagai pelaku tindak pidana bertugas membantu memperlancar tugas penyidik, penuntut umum, dan hakim dalam perkara anak nakal, baik di dalam maupun di luar sidang anak.

Adapun petugas kemasyarakatan terdiri dari:

1) Pembimbing Kemasyarakatan dari Departemen Kehakiman

2) Pekerja Sosial dari Departemen Sosial

3) Pekerja Sosial sukarela dari Organisasi Sosial Kemasyarakatan. (Hafrida: 2016).

Supaya penyidikan juga berjalan dengan lancar maka penyidik dari Polres Payakumbuh juga perlu meningkatkan hubungan kerja sama dengan BAPAS agar penelitian dan hasil penelitian terhadap anak dapat diselesaikan dengan segera.

Sehingga Hasil penelitian tersebut dapat diselesaikan dengan segera sebelum pihak penyidik menyerahkan anak dan barang bukti kepada Jaksa Penuntut Umum (JPU). BAPAS adalah salah satu unit pelaksana tekhnis di bidang pembinaan diluar lembaga pemasyarakatan. Balai ini bertugas memberikan bimbingan kemasyarakatan dan pengentasan anak. Itu sebabnya, eksistensi BAPAS sudah diakomodir dalam Undang-undang Sistem Peradilan Anak. Yang terpenting sekarang bagaimana memaksimalkan peranan BAPAS dalam sistem Peradilan Nasional.

Tugas pembimbing BAPAS tidaklah mudah, LAPAS dan para petugasnya diperlukan sejak dini, mulai dari proses penyidikan, persidangan di pengadilan hingga anak pelaku tindak pidana bersangkutan selesai menjalani hukuman.

Pembimbing kemasyarakatan (PK) memang bertugas membantu penyidik, penuntut umum dan hakim dalam perkara anak nakal serta membimbing, membantu dan mengawasi anak yang dijatuhi pidana bersyarat.

Dalam Kitab Undang-Undang Hukum Acara Pidana dikenal memiliki dua macam penyidik yakni Pejabat Polisi Negara Republik Indonesia dan Pejabat Pegawai Negeri Sipil tertentu yang diberi wewenang khusus oleh undang-undang (PPNS). Dalam hal perkara pidana yang dilakukan oleh anak-anak pada umumnya ketentuan yang dilanggar adalah peraturan pidana yang diatur dalam Kitab UndangUndang Hukum Pidana (KUHP), maka penyidikannya dilakukan oleh penyidik umum dalam hal ini adalah penyidik Polri. Penyidikan terhadap perkara pidana 
yang pelakunya anak-anak dilakukan oleh Pejabat Polri. (Afrida, 2016).

Meskipun penyidiknya adalah penyidik polri, akan tetapi tidak semua penyidik Polri dapat melakukan penyidikan terhadap perkara pidana yang dilakukan oleh anak-anak. Dalam Undang-Undang Pengadilan Anak dikenal adanya penyidik anak, sehingga penyidik inilah yang berwenang melakukan penyidikan. Adapun syarat khusus selaku penyidik untuk dapat melaksanakan penyidikan terhadap anak diatur dalam Undang-Undang Nomor 11 Tahun 2012 tentang Sistem Peradilan Pidana Anak sebagai berikut:

a. Telah berpengalaman sebagai Penyidik

b. Mempunyai minat, perhatian, dedikasi dan memahami masalah anak dan;

c. Telah mengikuti pelatihan tekhnis tentang Peradilan Anak. (Helviza, I., 2016).

Menjadi penyidik anak memang tidak cukup hanya kepangkatan yang memadai tetapi juga dibutuhkan pengalaman tugas dalam melaksanakan penyidikan. Di samping itu yang tidak kalah pentingnya adalah mengenai minat, perhatian, dedikasi dan pemahaman masalah anak, akan mendorong penyidik anak dalam menimba pengetahuan tentang masalah anak, sehingga dalam melaksanakan tugasnya penyidik akan memperhatikan kepentingan anak. (Supriyadi, 2015).

\section{SIMPULAN}

Dari hasil penelitian yang telah dilakukan maka dapat disimpulkan sebagai berikut yaitu pelaksanaan penyidikan terhadap anak yang terlibat dalam transaksi Narkotika di wilayah hukum Polres Payakumbuh yang dilakukan oleh penyidik pada dasarnya sudah sesuai dengan KUHAP dan Undang-undang Nomor 11 Tahun 2012 tentang Sistem Peradilan Pidana Anak yang berlaku walaupun dalam pelaksanaannya belum maksimal karena adanya keterbatasan. Hak-hak yang diberikan kepada tersangka anak ini pun antara lain berupa hak dihindari dari tindak kekerasan, didampingi penasehat hukum dan pembimbing kemasyarakatan, hak mengeluarkan pendapat, pandangan secara bebas, mendapat perawatan dan kesejahteraan, dan hak diperlakukan sama.

Kendala-kendala yang timbul dalam penyidikan terhadap anak yang terlibat dalam transaksi Narkotika di wilayah hukum Polres Payakumbuh antara lain yaitu waktu untuk melakukan penahanan terhadap anak sangat terbatas yaitu 7 hari dan dapat diperpanjang 8 hari sehingga penyidik harus ekstra cepat untuk bisa menyelesaikan berkas perkaranya, harusnya melakukan pemeriksaan ke laboratorium BPOM Padang yang harus diantar dan dijemput oleh penyidik, harus menunggu hasil penelitian BAPAS terhadap anak yang bersangkutan, dan belum adanya penyidik khusus anak. 
Ana Ramadhona: Pelaksanaan Penyidikan Terhadap Anak Yang Terlibat Dalam...

\section{DAFTAR PUSTAKA}

Nashriana, 2011, Perlindungan Hukum Pidana Bagi Anak di Indonesia, Rajawali Pers, Jakarta;

Marlina, 2009, Peradilan Pidana Anak di Indonesia, PT Refika Aditama, Bandung;

Moch Faisal Salam, 2002, Peradilan HAM Di Indonesia, Pustaka, Bandung;

Sudanto, A, 2017, Penerapan Hukum Pidana Narkotika di Indonesia. Jurnal Hukum ADIL, Vol.8, (No1), Hal.137-161;

Eleanora, Fransiska N, 2011, Bahaya Penyalahgunaan narkoba serta usaha pencegahan dan penanggulangannya. Jurnal Hukum, Vol XXV, (No.1), Hal.439-452.

Utami, Ika R, 2014, Kebijakan Aplikasi Dalam Tindak Pidana Narkotika Yang Dilakukan Oleh Anak Di Pengadilan Negeri Semarang. Jurnal Law Reform, Vol 9, (No.2), Hal. 98-109.

Hariyanto, Bayu P, 2018, Pencegahan Dan Pemberantasan Peredaran Narkoba Di Indonesia. Jurnal Daulat Hukum, Vol.1, (No.1), Hal.201-210

Zahra, A, 2017, Penerapan Asas Ultimatum Remedium Dalam
Rangka Perlindungan Anak

Pecandu Narkoba. Jurnal Law Reform, Vol 13, (No.1), Hal.18-29;

Helviza, I, 2016, Kendala-Kendala Badan Narkotika Nasional (BNN) Dalam Penanggulangan Penyalahgunaan Narkotika di Kota Banda Aceh, Jurnal Ilmiah Mahasiswa Pendidikan Kewarganegaraan Unsiah, Vol.1, (No.1), Hal.129-143;

Hafrida, 2016, Kebijakan Hukum Pidana Terhadap Pengguna Narkotika Sebagai Korban Bukan Pelaku Tindak Pidana. Jurnal Hukum Padjajaran, Vol.III, (No.1), Hal.173191;

Supriyadi, 2015, Penetapan Tindak Pidana Sebagai Kejahatan dan Pelanggaran Dalam UndangUndang Pidana Khusus. Jurnal Mimbar Hukum, Vol. XXVII, (No,3), Hal .390-402;

Rukmana, A. Indra, 2014. Perdagangan Narkotika dalam Perspektif Hukum Pidana Internasional. Jurnal Ilmu Hukum Legal Opinion, Vol.2,(Vol.1), Hal.1-8;

Dwiatmodjo, H. 2013, Pelaksanaan Dan Pembinaan Narapidana Tindak Pidana Narkotika. Jurnal Hukum Perspektif, Vol.XVIII, (No.2), Hal.64-72. 